\title{
Hedge Fund Ownership, Board Composition and Dividend Policy in the Telecommunications Industry
}

\author{
Eric Haye ${ }^{1}$ \\ ${ }^{1}$ Anisfield School of Business, Ramapo College of New Jersey, Mawah, New Jersey, USA \\ Correspondence: Eric Haye, Anisfield School of Business, Ramapo College of New Jersey, Mahwah, NJ 07430, \\ USA. Tel: 1-201-684-7347. E-mail: ehaye@ramapo.edu
}

Received: November 24, 2014

Accepted: January 1, 2015

Online Published: January 6, 2015

doi:10.5430/ijfr.v6n1p111

URL: http://dx.doi.org/10.5430/ijfr.v6n1p111

\begin{abstract}
This paper examines the impact of hedge fund ownership, mutual fund ownership, board composition and large block ownership on the dividend policy of telecommunications firms. The paper is intended to test the agency cost hypothesis for dividends, in which dividends serve as a substitute control mechanism in circumstances in which shareholder control has been attenuated. The evidence suggests that hedge fund ownership serves as a substitute for dividends as a corporate control mechanism to alleviate agency problems. However, the same case cannot be made for mutual fund ownership. The evidence also suggests that board independence increases the likelihood and the magnitude of a dividend payout. Furthermore, the results also indicate that the joint presence of independent boards and large shareholdings reduces the likelihood of a dividend payment. The latter two results suggest that greater independent board representation provides an effective medium for shareholders to extract dividends as well as a complement to top shareholder concentration in relieving agency costs. Overall, the results provide ample support for an agency-theoretic explanation of dividends.
\end{abstract}

Keywords: dividend policy, ownership structure, corporate governance, agency costs

\section{Introduction}

The theoretical literature on dividends as an alternate control devise to reduce agency problems is well-established. Financing the dividend by issuing new shares is desirable since investors obtain information regarding management's intentions (Rozeff (1982)). Dividends require firms to raise funds externally, subjecting corporate decisions and operations to greater external market scrutiny. Managers have an incentive to minimize agency costs in order to minimize the cost of financing (Easterbrook (1984)). Managers, particularly for firms with low growth prospects generating substantial cash flow, have an incentive to accumulate free cash flow to invest in negative-NPV spending proposals or other wasteful activities. Dividends can alleviate the agency costs of equity by reducing excess cash (Jensen (1986)).

However, the impact of institutional ownership on agency conflict through dividends is not straightforward. Institutional investors may have a strong aversion to monitoring or may be poor monitors, and would prefer to use the dividend and the scrutiny of the capital markets as an alternate control mechanism. For shareholders who choose to monitor, the benefits of monitoring are not commensurate relative to the proportion of their holdings (Grossman and Hart (1980), Easterbrook (1984)). Many institutions have a tax preference for dividends. In addition, institutional investors may be subject to prudent man rules restricting them from investing in non-dividend paying stocks (Grinstein and Michaely (2005)). All of this suggests that institutions favor dividend payments. Both Moh'd, Perry \& Rimbey (1995) and Short, Zhang \& Keasey (2002) find that institutional shareholdings are positively related to dividend payout. Khan (2006) reports a positive relationship between insurance companies' ownership concentration and dividends.

Conversely, there have been a number of studies that have identified a significant negative association between institutional ownership and dividends. Grinstein and Michaely (2005) report that within their dividend-paying sample institutional owners do not have a preference for high dividend-paying stocks. Truong and Heaney (2007) find that dividend payouts are lower if the largest shareholder is an insider or a financial institution. Examining a sample of bank holding companies, $\mathrm{Wu}$ and Jia (2010) find that institutional ownership is negatively related to dividend yield, and that this is particularly the case for insurance companies and individual investment advisers. 
These results imply that institutional investors use their voting power as well as access to and influence over management to reduce agency costs, and that their shareholdings serve as an alternate control devise to dividend payout.

Based on the effect of institutional holdings on stock price reactions to dividend announcements, Amihud and Li (2006) conclude that institutional investors are more informed and sophisticated than retail investors. Among institutional investors, mutual funds and hedge funds arguably have the more activist perspective. Mutual funds are not subject to prudent-man investment rules to the same degree as other institutions, such as pension funds, insurance companies and bank trust funds (Del Guercio (1996)), while hedge funds are completely exempt from these restrictions.

Hedge funds, in particular, are in a special category for a number of reasons. They have limits on the number of investors and tend to attract more experienced and wealthy investors. Hedge funds are also differentiated from mutual funds and other institutional investors in that they do not face portfolio diversification restrictions, may use derivatives and leverage, and have incentive-pay compensation structures. There is evidence indicating that hedge fund activism plays a substantive role in corporate affairs. Clifford (2008) finds that firms targeted by activist hedge funds earn greater positive excess returns than firms targeted by hedge funds with passive intentions. He also finds that firms targeted by activist hedge funds experience increases in operating efficiency in the year following the acquisition, a result not obtained by activism on the part of pension funds, mutual funds and other shareholder groups. Klein and Zur (2009) find that the target firms of activist hedge funds earn higher positive abnormal stock returns than other activist target firms. Brav, Jiang, Partnoy \& Thomas (2008) find that hedge fund target firms experience CEO pay declines and increases in CEO turnover rates. These results suggest that hedge funds, and perhaps mutual funds, may serve as effective monitors and that their ownership stakes may serve as a substitute control mechanism to dividends. To-date, there is virtually no research on the impact of hedge fund and mutual fund ownership on corporate dividend policy.

Board composition may also play a role in mitigating agency costs. Greater independent board member representation may serve to countervail agency problems. External board members play an important role in conducting board activities that pose substantial agency risks for outside investors, such as hiring executives and setting executive compensation (Fama and Jensen (1983)). They have an incentive to serve as competent representatives for investors since their future marketability is directly related to their performance (White (1990)). Sarbanes-Oxley governance reforms also create reputational and litigation incentives for independent directors to safeguard outside shareholders' interests (Sharma (2011)). Greater board independence serves to eliminate information asymmetries and enhances the ability of outside shareholders to compel managers to pay dividends. There is empirical evidence supporting these contentions. Although White (1990) finds that board independence is not significantly related to dividend payments or the magnitude of annual dividend changes, Sharma (2011), Jiraporn and Ning (2006) and Hu and Kumar (2004) find that firms with independent boards have a greater propensity to pay dividends. Adjaoud and Ben-Amir (2010) find that board composition is positively and significantly related to dividend payout ratios, while Jiraporn and Ning (2006) find that firms with more independent boards have significantly higher dividend yields.

The purpose of this paper is to examine the impact of hedge fund ownership, mutual fund ownership and board structure on the dividend policy of a sample of telecommunications companies. The telecommunications sector has tended to be one of the higher-paying dividend sectors. The remainder of this article is as follows - Section 2 develops the hypothesis tests and predicted signs. Section 3 discusses the sample and data. Section 4 reports the results and Section 5 concludes the paper.

\section{Hypothesis Tests}

Table 1 provides the variable definitions and predicted signs. Four measures of dividend policy will be used as dependent variables - (i) the dividends-to-earnings ratio, (ii) the dividends-to-total assets ratio, (iii) the dividends-to-sales ratio and (iv) a dividend dummy variable used in the logit specification. 
Table 1. Variable definitions and predicted signs

\begin{tabular}{|c|c|c|}
\hline Dependent Variables & Definition & \\
\hline Dividends/Earnings & $\begin{array}{l}\text { Total cash dividends divided by earnings available to } \\
\text { common stockholders. }\end{array}$ & \\
\hline Dividends/Total Assets & Total cash dividends divided by total assets. & \\
\hline Dividends/Sales & Total cash dividends divided by sales revenue. & \\
\hline Dividend dummy & $\begin{array}{l}=1 \text { if the dividend yield of the firm is greater then } 0 ; 0 \\
\text { otherwise. }\end{array}$ & \\
\hline Independent Variables & Definition & Predicted Sign \\
\hline Board independence & $\begin{array}{l}\text { The percentage of independent directors is measured by } \\
\text { the number of independent directors divided by the total } \\
\text { number of board members. }\end{array}$ & + \\
\hline Governance interaction & $\begin{array}{l}\text { A dummy variable that is } 1 \text { if more than } 60 \% \text { of the } \\
\text { board is composed of independent directors multiplied by } \\
\text { the percentage of stock held by the largest principal } \\
\text { shareholder; } 0 \text { otherwise. }\end{array}$ & $?$ \\
\hline Hedge fund ownership & The percentage of common shares held by hedge funds. & - \\
\hline Mutual fund ownership & The percentage of common shares held by mutual funds. & - \\
\hline $\begin{array}{l}\text { Natural log of total } \\
\text { assets }\end{array}$ & $\begin{array}{l}\text { The natural logarithm of total assets serves as a proxy for } \\
\text { the size of the firm. }\end{array}$ & + \\
\hline EBIT-to-sales ratio & $\begin{array}{l}\text { Earnings before interest and taxes divided by sales } \\
\text { revenues. Serves as a proxy for ability to generate cash } \\
\text { flow. }\end{array}$ & + \\
\hline Market-to-book ratio & $\begin{array}{l}\text { The market capitalization of the firm divided by total } \\
\text { common stockholders' equity. Used to proxy the firm's } \\
\text { growth prospects. }\end{array}$ & - \\
\hline Beta & $\begin{array}{l}\text { The equity beta of the firm. Used to measure cash flow } \\
\text { volatility. } 60 \text {-month regression line. }\end{array}$ & - \\
\hline
\end{tabular}

If the presence of sophisticated investors such as hedge funds and mutual funds in the firm's ownership structure mitigates the need for dividends as a control mechanism, then dividends should be negatively related to hedge fund ownership and mutual fund ownership. This should particularly be the case for hedge funds as a result of their more activist perspective, exemption from prudent-man regulations and ability to use leverage and derivatives to acquire shares.

Board independence is measured by the percentage of outside, or external, directors. Greater board independence should enhance the ability of outside shareholders to employ dividend payments as a disciplinary mechanism. As a result, firms with a greater proportion of independent directors should have a greater propensity to pay dividends and should pay higher dividends.

In keeping with $\mathrm{Hu}$ and Kumar (2004) a governance interaction variable is included to test for the combined impact of board composition and large-block ownership on dividend policy. If independent boards and greater principal, or top, ownership concentration serve as complements, then the sign on this term should be negative, or firms with the presence of both simultaneously are less likely to pay dividends and will pay lower dividends. However, a positive sign would indicate that the two serve as substitute disciplining mechanisms.

Larger firms tend to be more complex organizations and are presumably subject to greater agency problems. With their lower bankruptcy risks and enhanced access to the capital markets they face lower capital and floatation costs than their smaller counterparts. As a result, firm size and dividend payments should be directly related. Firm size is measured by the natural log of total assets. There have been a number of studies that have identified a positive relationship between the natural log of total assets and dividend payout (see Jiraporn and Ning (2006), Adjaoud and Ben-Amir (2010), Warrad, Abed and Khriasat (2012) and Thanatawee (2013)). 
The EBIT-to-sales ratio, in which EBIT is earnings before interest and taxes, is included to measure the firm's ability to generate cash flow and profits. Firms with higher operating cash flow relative to sales are more likely to realize free cash flow and, therefore are more capable of paying dividends and making higher dividend payments.

Cash flow volatility, or earnings risk, is measured by the firm's equity beta. Firms with high operating and financial leverage have more volatile cash flows, creating a need for more frequent capital market financing. These firms will pay lower dividends in order to preserve internal resources and minimize the need for outside capital (Rozeff (1984)). Schooley and Barney (1994), Moh'd, Perry and Rimbey (1995) and Harada and Nguyen (2011) find a negative relationship between the beta and dividend payout. Casey and Dickens (2000), in their study of bank holding companies, uncover an insignificant relationship between the beta and dividend payout.

Growth prospects or investment opportunities are proxied by the market capitalization of the firm divided by total common stockholders' equity, or the market-to-book ratio of common equity. Firms with good growth prospects will have a greater need for financing and are therefore less likely to pay dividends. However, it may be worth noting that there may be situations in which managers may feel compelled to affirm their protection of shareholders rights. As a result, firms with better growth prospects may pay higher dividends in order to secure future external financing at reasonable rates (see LaPorta et. al. (2000)).

\section{Sample and Data}

The data consists of 77 firms with a presence in the telecommunications industry and is obtained from the Thomson Bankers One data base. All data refer to the year 2012. 52\% of the sample firms have their primary SIC code from telephone companies (12 firms or 16\% of the sample), cable and other pay television services (11 firms or 14\% of the sample), communications services not elsewhere classified ( 9 firms or 12\%) and radio broadcasting stations (8 firms or $10 \%$ ).

The average firm in the sample paid dividends of $\$ 109$ million with a standard deviation of $\$ 341$ million. The descriptive statistics for the dependent and independent variables appear in Table 2. Panel A shows that the dividends-to-earnings ratio has a mean of $15.27 \%$. The average dividends-to-total assets ratio is $0.63 \%$ and the average dividends-to-sales ratio is $1.17 \%$. The percentage of dividend-paying firms in the sample is $29 \%$.

The average firm has sales of $\$ 4,191$ million with a median of $\$ 715$ million. From Panel B, the average firm has total assets of $\$ 9,166$ million with a standard deviation of $\$ 23,238$ million. Both the sales and total assets statistics indicate that the sample is comprised of many large firms, but that there is a great deal of variation in firm size. The EBIT margin of $16.93 \%$ reveals that the average firm in the sample was generating substantial operating cash flow in 2012. The sample firms also posted a relatively high average market-to-book ratio of 9.24 . The average historical 5 -year beta was 1.21 . On average, hedge funds owned $12.31 \%$ of the outstanding common stock, while mutual funds owned $32.29 \%$. About $75 \%$ of the boards are comprised of independent directors.

Table 2. Descriptive statistics

\begin{tabular}{lcc}
\hline & Mean & Standard Deviation \\
\hline & Panel A: Dependent Variables \\
\hline Dividends-to-earnings & $15.27 \%$ & $25.03 \%$ \\
Dividends-to-total assets & $0.63 \%$ & $1.17 \%$ \\
Dividends-to-sales & $1.17 \%$ & $2.35 \%$ \\
Dividend-paying firms & $28.57 \%$ & $0.45 \%$ \\
\hline \multicolumn{3}{c}{} \\
\hline Hedge fund ownership & Panel B: Independent Variables \\
Mutual fund ownership & $12.31 \%$ & $11.54 \%$ \\
Independent board composition & $32.29 \%$ & $17.03 \%$ \\
Governance interaction & $75.11 \%$ & $14.61 \%$ \\
Total assets (in millions $)$ & $13.48 \%$ & $14.11 \%$ \\
EBIT-to-sales ratio & $\$ 9,166$ & $\$ 23,238$ \\
Market-to-book ratio & $16.93 \%$ & $13.53 \%$ \\
Beta & 9.24 & 50.99 \\
N= number of observations $=77$ firm & 1.21 & 0.81 \\
\hline
\end{tabular}


When comparing the dividend-paying firms to the non-dividend paying sample firms, the dividend-paying firms are larger (average total assets of $\$ 22,870$ million versus $\$ 3,685$ million), more profitable (average EBIT margin of $21.2 \%$ vs. $15.2 \%$ ) and riskier (average beta of 1.28 vs. 1.18 ), but with more modest growth prospects (average market-to-book ratio of 2.27 vs. 12.02) than the non-dividend paying sample firms. The dividend-paying firms also have lower hedge fund ownership participation $(7.58 \%$ vs. $14.2 \%)$, slightly higher mutual fund ownership participation (34.3\% vs. $31.5 \%)$ and more independent boards $(77.9 \%$ vs. $74 \%)$ than the non-dividend paying sample.

Table 3 presents the correlation coefficient matrix of all dependent variables. The highest correlation is between mutual fund ownership and independent board representation (at +0.241$)$ while the lowest correlation is between mutual fund ownership and the governance interaction binary variable (at -0.233 ). Taken together, the matrix suggests the absence of multicollinearity in the sample.

Table 3. Pearson correlation coefficients

\begin{tabular}{lllllllll}
\hline & $(1)$ & $(2)$ & $(3)$ & $(4)$ & $(5)$ & $(6)$ & $(7)$ & $(8)$ \\
\hline Total assets (1) & 1.000 & 0.109 & 0.042 & -0.048 & -0.127 & 0.107 & 0.009 & -0.151 \\
EBIT-to-sales (2) & & 1.000 & -0.060 & -0.005 & -0.154 & -0.028 & 0.009 & 0.004 \\
Market price-to-book (3) & & & 1.000 & -0.022 & 0.093 & 0.055 & -0.137 & -0.102 \\
Beta (4) & & & & 1.000 & 0.076 & 0.109 & -0.047 & -0.079 \\
Hedge fund ownership (5) & & & & & 1.000 & -0.057 & 0.226 & 0.078 \\
Mutual fund ownership (6) & & & & & & 1.000 & 0.241 & -0.233 \\
Independent board percentage (7) & & & & & & & 1.000 & 0.159 \\
Governance interaction binary variable (8) & & & & & & & & 1.000 \\
\hline
\end{tabular}

\section{Regression Results}

Table 4 presents the results of the regression analysis. A number of firm control variables are employed. The natural $\log$ of total assets is included to account for firm size. The EBIT margin, or the EBIT-to-sales ratio, is used to control for cash flow and firm profitability. The market-to-book ratio, or the ratio of the firm's market capitalization versus its book value of equity, is included to proxy investment opportunities. The beta is included to account for the effects of cash flow volatility caused by operating and financial leverage.

In equation 1, in which the dependent variable is the dividend payout ratio, the sign on the hedge fund ownership coefficient is negative and significant $(\mathrm{t}=-2.75$, significant at the $1 \%$ level). Holding all else constant, referring to the estimated coefficient on hedge fund ownership in this equation, a one standard deviation increase in hedge fund ownership (11.54\%) leads to a $6.43 \%$ decrease in the dividend payout ratio, or a $42 \%$ decrease in the dividend payout ratio from its mean value (Note 1). Similar sign and significance results occur in the remaining equations. In equation 2, in which the dependent variable is the dividends-to-total assets ratio, $(\mathrm{t}=-3.51$, significant at the $1 \%$ level) and equation 3, in which the dividends-to-sales ratio is the dependent variable $(\mathrm{t}=-3.54$, significant at the $1 \%$ level). Equation 4 presents the logit regression results, in which the dependent variable is a binary variable equal to one if the firm has a dividend yield greater than zero and zero otherwise. Equation 4 reflects the likelihood of the firm making a dividend payment. In accord with the OLS regression results of equations $1-3$, the logit regression results indicate that firms with greater hedge fund ownership stakes are significantly less likely to pay dividends. These results support the hypothesis that hedge funds serve as an alternative to dividends as a disciplining mechanism.

Although the coefficient on the mutual fund ownership variable has the predicted sign across all four equations, it is statistically insignificant throughout. This confirms the a priori assertion that mutual fund ownership participation does not play as substantial a role in disciplining management as hedge funds.

The results also suggest the greater independent board representation can mitigate agency costs by enabling shareholders to extract more dividends as well as increasing the likelihood of a dividend payment. The sign on the independent board representation variable is positive for all four equations, although insignificant in equation 1. It is highly significant in equation 2 (dividends-to-total assets as dependent variable) and equation 3 (dividends-to-sales as dependent variable). In addition, the governance interaction variable is negative in all four equations but significant only in equations 1 and the logit equation 4. These results provide some confirmation of the $\mathrm{Hu}$ and 
Kumar (2004) conclusion that firms with substantial independent board representation have a reduced need for dividends as a disciplinary mechanism in the face of greater principal ownership concentration.

Table 4. Regression results

\begin{tabular}{lllll}
\hline Dependent Variables & $(1)$ & $(2)$ & $(3)$ & $(4)$ \\
& Dividends-to-Earnings & $\begin{array}{l}\text { Dividends-to-Total } \\
\text { Assets }\end{array}$ & $\begin{array}{l}\text { Dividends-to-Sales } \\
\text { Dividend Dummy }\end{array}$ \\
\hline Independent Variables & & & & \\
Constant & 1.126 & $-1.461^{* * *}$ & $-3.043^{* * *}$ & $-6.280^{* * *}$ \\
Hedge fund ownership & $(0.055)$ & $(-3.20)$ & $(-2.66)$ & $(-2.88)$ \\
& $-0.557^{* * *}$ & $-0.029^{* * *}$ & $-0.065^{* * *}$ & $-0.083^{* *}$ \\
Mutual fund ownership & $(-2.75)$ & $(-3.51)$ & $(-3.54)$ & $(-2.06)$ \\
& -0.240 & -0.007 & -0.017 & -0.030 \\
Board independence & $(-1.35)$ & $(-0.93)$ & $(-0.71)$ & $(-1.16)$ \\
& 0.191 & $0.025^{* * *}$ & $0.040^{* * *}$ & $0.051^{* *}$ \\
Governance interaction & $(0.92)$ & $(3.29)$ & $(2.76)$ & $(2.04)$ \\
& $-0.325^{*}$ & -0.013 & -0.020 & $-0.073^{* *}$ \\
Natural log of total assets & $(-1.89)$ & $(-1.61)$ & $(-0.89)$ & $(-1.99)$ \\
& 1.029 & 0.098 & $0.317^{*}$ & $0.503^{* *}$ \\
EBIT-to-sales ratio & $(0.67)$ & $(1.26)$ & $(1.68)$ & $(2.40)$ \\
& 0.166 & 0.011 & 0.029 & 0.023 \\
Market-to-book ratio & $(0.80)$ & $(0.91)$ & $(0.98)$ & $(1.06)$ \\
& $0.140^{* * *}$ & $0.005^{* * *}$ & $0.005^{* * *}$ & -0.173 \\
Beta & $(9.26)$ & $(7.65)$ & $(4.06)$ & $(-1.06)$ \\
& 5.828 & 0.005 & -0.111 & 0.405 \\
N & $(1.44)$ & $(0.04)$ & $(-0.41)$ & $(0.96)$ \\
$\mathrm{R}^{2} /$ pseudo-R & 77 & 77 & 77 \\
F-statistic/LR & 77 & 0.2393 & 0.2539 & 0.3051 \\
& 0.2067 & $2.56^{* *}$ & $2.89^{* * *}$ & $28.11^{* * *}$ \\
\end{tabular}

With regard to the other control variables, the natural log of total assets has the predicted positive sign throughout, but is significant only in the dividends-to-sales and dividend dummy equations. The EBIT margin has the predicted positive sign in all four equations but is insignificant throughout. The market-to-book ratio has an unexpected positive sign in the OLS equations, and is negative but insignificant in the logit equation. The estimated coefficient on the beta has the correct sign in equation 3 but is insignificant in all four equations.

\section{Conclusion}

This article investigates the effect of hedge fund ownership, mutual fund ownership, board structure and principal ownership-board structure interaction on the dividend policy of a sample of telecommunications companies. The underlying hypotheses under examination are based on the agency perspective of dividends, i.e., that the dividend serves as a mechanism to countervail managerial entrenchment and reduce agency costs.

Three important findings come from this study. First of all, the empirical evidence strongly supports the contention that hedge fund involvement in ownership serves as an effective deterrent in mitigating agency problems, thereby reducing the need for dividends as well as the likelihood of a dividend payment. However, the results do not make the same case for mutual fund ownership; although mutual fund ownership and dividends are inversely related in all four tests conducted, the relationship is statistically insignificant. Secondly, the evidence also suggests that more independent boards increase both the likelihood and magnitude of a dividend payment. Lastly, a interactive variable equal to the percentage of shares held by the largest shareholder multiplied by a dummy variable equal to one if independent board concentration exceeds $60 \%$ is employed to test the combined effect of board structure and concentrated top shareholdings on dividend policy. The evidence indicates that the joint presence of independent boards and large shareholdings reduces the likelihood of the firm making a dividend payment, and some evidence 
suggesting the magnitude of the dividend payment as well. This third result shores up the notion that independent boards and concentrated principal shareholdings serve as complementary governance mechanisms in controlling and disciplining management. These results contribute to the existing scholarship analyzing the agency impact of ownership and board structure on dividend policy and, in particular, the role of hedge funds in the corporate control and dividend determination process.

\section{References}

Adjaoud, F., \& Ben-Amir, W. (2010). Corporate governance and dividend policy: Shareholders' protection or expropriation? Journal of Business Finance \& Economics, 37, 648-667.

Amihud, Y., \& Li, K. (2006). The declining information content of dividend announcements and the effects of institutional holdings. Journal of Financial and Quantitative Analysis, 41, 637-660.

Brav, A., Jiang, W. Partnoy, F., \& Thomas, R. (2008). Hedge fund activism, corporate governance and firm performance. Journal of Finance, 63, 1729-1775.

Casey, K.M., \& Dickens, R.N. (2000). The effects of tax and regulatory changes on commercial bank dividend policy. The Quarterly Review of Economics and Finance, 40, 279-293.

Del Guercio, D. (2006). The distorting effect of the prudent-man laws on institutional equity investments. Journal of Financial Economics, 40, 31-62.

Easterbrook, F. H. (1984). Two agency-cost explanations of dividends. American Economic Review, 74, 650-659.

Fama, E., \& Jensen, M. (1983). Separation of ownership and control. Journal of Law and Economics, 26, 301-325. http://dx.doi.org/10.1086/467037

Grinstein, Y., \& Michaely, R. (2005). Institutional holdings and payout policy. Journal of Finance, 60, 1389-1426. http://dx.doi.org/10.1111/j.1540-6261.2005.00765.x

Harada, K., \& Nguyen, P. (2011). Ownership concentration and dividend policy in Japan. Managerial Finance, 37 , 362-379.

Hu, A., \& Kumar, P. (2004). Managerial entrenchment and payout policy. Journal of Financial and Quantitative Analysis, 39, 759-790. http://dx.doi.org/10.1017/S0022109000003203

Jensen, M. (1986). Agency costs of free cash flow, corporate finance and takeovers. American Economic Review, 76, 323-339.

Jiraporn, P., \& Ning, Y. (2006). Dividend policy, shareholder rights and corporate governance. Journal of Applied Finance, Fall/Winter, 24-36.

Khan, T. (2006). Company dividends and ownership structure: Evidence from UK panel data. The Economic Journal, 116, 172-189. http://dx.doi.org/10.1111/j.1468-0297.2006.01082.x

Klein, A., \& Zur, E. (2009). Entrepreneurial shareholder activism: Hedge funds and other private investors. Journal of Finance, 64, 187-229.

LaPorta, R., Lopez-De Salinas, F., Schleifer, A., \& Vishny, R. (2000). Agency problems and dividend policy around the world. Journal of Finance, 55, 1-33. http://dx.doi.org/10.1111/0022-1082.00199

Moh'd, M., Perry, L., \& Rimbey, J. (1995). An investigation of the dynamic relationship between agency theory and dividend policy. The Financial Review, 30, 367-385. http://dx.doi.org/10.1111/j.1540-6288.1995.tb00837.x

Rozeff, M. (1982). Growth, beta and agency costs as determinants of dividend payout ratios. Journal of Financial Research, 5, 249-259.

Schooley, D., \& Barney, Jr, L.D. (1994). Using dividend policy and managerial ownership to reduce agency costs. The Journal of Financial Research, 17, 363-373.

Sharma, V. (2011). Independent directors and the propensity to pay dividends. Journal of Corporate Finance, 17, 1001-1015. http://dx.doi.org/10.1016/j.jcorpfin.2011.05.003

Shleifer, A., \& Vishny, R. (1997). Large shareholders and corporate control. Journal of Political Economy, 95, 461-488.

Short, H., Zhang, H., \& Keasey, K. (2002). The link between dividend policy and institutional ownership. Journal of Corporate Finance, 8, 105-122. 
Thanatawee, Y. (2013). Ownership structure and dividend policy: Evidence from Thailand. International Journal of Economics \& Finance, 5, 121-132.

Truong, T., \& Heaney, R. (2007). Largest shareholder and dividend policy around the world. The Quarterly Review of Economics \& Finance, 47, 667-687.

Warrad, L., Abed, S., Khriasat, O., \& Al-Shiekh, I. (2012). The Effect of Ownership Structure on Dividend Payout Policy: Evidence from Jordanian Context. International Journal of Economics \& Finance, 4, 187-195.

Wen, Y., \& Jia, J. (2010). Institutional Ownership, managerial ownership and dividend policy in bank holding companies. International Review of Accounting, Banking and Finance, 2, 8-21.

White, L. (1996). Executive Compensation and Dividend Policy. Journal of Corporate Finance, 2, 335-358.

\section{Note}

Note 1. A one standard deviation increase in hedge fund ownership $(15.4 \%)$ leads to a $(15.4 \%)(-0.557)=-6.43 \%$ decrease in dividend payout from its mean, which is $-6.43 \% / 15.27 \%=-0.421$ or a $42.1 \%$ decrease in dividend payout. 